\title{
Science East and West: reflections of Peter Kapitza
}

\section{Nevill Mott}

Peter Leonidovich Kapitza was born on July 9,1894 , and began his scientific work in the Polytechnic Institute of $\mathrm{St}$ Petersburg, from which he graduated in 1918. In 1921 he was sent by the Soviet authorities to work under Lord Rutherford in Cambridge, where he stayed until 1934, the Royal Society Mond Laboratory being built especially for his work on the development and effects of high magnetic fields and low temperatures. During this time he retained his Soviet citizenship, returning to Russia from time to time and telling his friends that he thought he was the only man of his country with a passport endorsed for unlimited journeys. However, in 1934, while attending a conference in Leningrad to celebrate the one-hundredth anniversary of the birth of Mendelyev, he was told that he could not return to Britain, and would have to continue his work in the Soviet Union. I was at the same conference, and remember the impression that Kapitza's Rover car, driven from Bergen round the gulf of Finland, made among the few official cars in the streets of Leningrad. In Russia he continued work in lowtemperature physics, for which he was awarded a Nobel prize in 1978; after the War he was accused of giving wrong advice about oxygen production and was excluded from his laboratory for several years; rehabilitated, he turned to plasma physics (not nuclear energy as is sometimes thought), and in the past few years has been able to travel abroad.

This book, translated from the Russian, contains a collection of articles and addresses delivered by Kapitza during the past 50 years. Many have appeared elsewhere, for instance "Recollections of Lord Rutherford" and a biographical memoir of L.D. Landau published by the Royal Society, of which Kapitza is a Fellow. His reverence for and gratitude to Rutherford are well known; he writes:

... in the year that Rutherford died there disappeared forever the happy days of free scientific work which gave us such delight in our youth. Science has lost her freedom. Science has become a productive force. . ., rich but enslaved, part of her veiled in secrecy.

Sir Nevill Mott is Emeritus Professor of Physics at Cambridge University; he knew Kapitza well between 1930 and 1934 .

\section{IMAGE \\ UNAVAILABLE FOR COPYRIGHT REASONS}

Experiment, Theory, Practice: Articles and Addresses of P.L. Kapitza. Boston Studies in the Philosophy of Science, Vol.46. Pp.429. (Reidel: 1980.) Hardback Df1.90, $\$ 47.35$; paperback Dfl.28, $\$ 14.75$.

\section{Peter Kapitza, July 1973}

He writes, too, a moving appreciation of Paul Langevin, and of other figures from the past. From the past few years, when he could travel, come addresses to international bodies, such as one on the impact of modern scientific ideas on society to the Unesco symposium on the centenary of Albert Einstein. A few sentences will reflect his views about the way society is going in the developed countries of East and West alike.

The state compels a person to abide by its laws, and society compels him to live in accordance with his traditions. After a certain degree of well-being has been reached people begin to lose their liberty as their prosperity increases, and already the freedom of the individual in the developed countries is extremely limited. Modern society strives to organise people's lives in such a way that they will have an impression of freedom despite their lack of it. This is achieved by means of propa- ganda and by turning people's interest towards sport, sex and entertainment so as to distract them from reality. Such were the principles on which society was organised in Aldous Huxley's Brave New World.

Kapitza seems to feel that it is not so very different in East and West. And in view of this, perhaps the most interesting parts of the book for the Western reader are his addresses to the Presidium of the Academy of Sciences of the USSR, for instance one in 1964, "The Effectiveness of Scientific Work". Here perhaps East and West do not appear so equal. He writes, in criticizing the situation in his own country:

An important factor in morale is to take part in scientific life abroad - at conferences and similar gatherings. As yet we take little part in them. Our delegates are still only one quarter or one fifth as many as those of the USA or other countries [are they now as many?] and often the delegates are selected by bureaucratic methods. . .

And in the same article, he writes that now nearly all those who should be leaders of science spend their time on committees, how every rouble must be accounted for even though money for research is not lacking. A director

cannot dismiss anyone, nor can he provide any incentive. The fettering of the Director, his restricted role in this important matter, is one of the reasons for the low efficiency of our institutes.

The book reveals Peter Kapitza's qualities that all his friends know well - his enormous courage, irrepressible vitality and humour. On humour, writing about theory and experiment, he quotes from the novel, Gentlemen Prefer Blondes, "that classical American work. . 'Love is a good thing but a golden bracelet is forever'." His memory plays him wrong (or does he, as seems hardly credible, quote from a Russian translation?). What Anita Loos wrote in 1925 was "kissing your hand may make you feel very, very good but ...". However, the point that Kapitza makes is that "theory is a good thing but a good experiment lasts for ever". Rutherford would have agreed, with the last part at any rate. 